AT-TAJDID: Jurnal Pendidikan Dan Pemikiran Islam

(p-ISSN: 2548-5784 |e-ISSN: 2549-2101)

Vol. (04 ) Nomor. (01), (Januari-Juni) (2020), (Halaman)(67-74)

Doi: http://dx.doi.org/10.24127/att.v4i01.1189

\title{
PENGARUH GAYA KEPEMIMPINAN OTORITER PADA USIA REMAJA
}

\author{
Irinne Fauz Yusria ${ }^{1}$ \\ Universitas Muhammadiyah Malang \\ irinnefauz@gmail.com \\ Dinda Putri Halilintar ${ }^{2}$ \\ Universitas Muhammadiyah Malang \\ dindahalilintar19@gmail.com \\ Muslimah Paxia Ilyas ${ }^{3}$ \\ Universitas Muhammadiyah Malang \\ muslimahpaxia@webmail.umm.ac.id \\ Nur Qolbiyah Kholisoh ${ }^{4}$ \\ Universitas Muhammadiyah Malang \\ nurqolbiyahk@gmail.com
}

\begin{abstract}
Abstrak
Gaya kepemimpinan otoriter adalah gaya seorang pemimpin yang memusatkan segala keputusan dan kebijakan diambil dari dirinya tanpa harus bertanya atau melihat bagaimana para anggota bawahannya. Segala semua keputusan atau melakukan kegiatan pada gaya otoriter ini seepenuhnya dikontrol oleh pemimpin. Metode yang digunakan pada penelitian ini adalah metode library research atau biasa disebut dengan studi kepustakaan. Penelitian ini bertujuan untuk mengetahui pengertian dari kepemimpinan dan gaya kepemimpinan otoriter, untuk mengetahui kebutuhan-kebutuhan pada anak usia remaja, pengaruh gaya kepemimpinan otoriter terhadap anak usia remaja, untuk mengetahui sisi positif dan negatif dari kepemimpinan otoriter bagi anak usia remaja, serta untuk mengetahui pengaruh jangka pendek dan jangka panjang dari penerapan pola asuh otoriter bagi anak usia remaja. Orang tua dan guru yang mendidik anaknya dengan gaya otoriter ini cenderung lebih mendikte anak dan kurang memiliki hubungan yang erat terhadap anak atau peserta didik tersebut. Sangat jarang dampak positif yang dihasilkan dari gaya kepemimpinan otoriter ini, kecuali orang tua dalam memerintah dan menghukum anak tersebut dapat memberikan alasan mengapa anak tersebut mendapatkan hukuman seperti itu.
\end{abstract}

Kata kunci : kepemimpinan otoriter, usia remaja.

\begin{abstract}
:
Authoritarian leadership style is the style of a leader who centralize all decisions and policies taken from her tan pa have to ask or look at how members of his subordinates. All decisions or activities in this authoritarian style are fully controlled by the leader. The method used in this study is the library research method or commonly referred to as library studies. This study aims to determine the understanding of leadership and authoritarian leadership style, to determine the
\end{abstract}


needs of adolescents, the influence of authoritarian leadership styles on adolescents, to find out the positive and negative sides of authoritarian leadership for adolescents, as well as to determine the effect short-term and long-term implementation of authoritarian parenting for adolescents. Parents and teachers who educate their children in an authoritarian style tend to dictate more to children and have less close relations with the child or students. Very rarely the positive effects resulting from this authoritarian leadership style, unless the parents in governing and punishing the child can give reasons why the child is getting such a punishment.

Keyword: authoritarian leadership, adolescence

\section{A. PENDAHULUAN}

Remaja merupakan suatu periode transisi antara masa kanak-kanak menuju masa dewasa. Masa remaja biasanya berada pada usia 13-18 tahun dan ada beberapa yang berpendapat sampai usia 20 tahun. Penentangan yang terjadi pada anak usia remaja terhadap aturan-aturan bukanlah hal yang baru, karena pada masa ini mereka terfokus pada pencarian jati diri. Masa remaja bisa juga dinilai sebagai fase kehidupan yang sangat sulit bagi individu itu sendiri serta bagi orang tua dan pendidik karena segala hal yang dilakukan atau difikirkan remaja akan mempengaruhi dan akan tertanam seumur hidupnya. Disini segala perilaku orang-orang terdekatnya termasuk orang tua dan guru akan mempengaruhi kepribadian anak. Kepemimpinan merupakan kemampuan dalam mempengaruhi orang lain, sehingga dalam mempengaruhi tergantung dengan gaya yang akan digunakannya. Gaya kepemimpinan memiliki variasi yang berbeda beda, diantaranya adalah gaya kepemimpinan otokrasi/otoriter, gaya kepemimpinan permisif, gaya kepemimpinan demokrasi, gaya kepemimpinan paternalistis, gaya kepemimpinan kharismatis, gaya kepemimpinan administratif/ eksekutif, dan gaya kepemimpinan situasional (Hidayat, 2019).

Gaya kepemimpinan otoriter yang dilakukan oleh guru dan orang tua pada anak memiliki sifat membatasi, menghukum, dan menuntut anak agar tunduk sesuai dengan standar tingkah laku yang ditetapkan oleh orang tua tanpa adanya kehangatan dalam mengasuh, serta anak tidak diperkenankan untuk mengeluarkan pendapat dalam sekolah/ keluarga (Niputu, 2016). Pola asuh otoriter cenderung menentukan apa yang harus dilakukan atau dipilih anak adalah apa yang terbaik menurut orang tuanya. Pola asuh otoriter dari orang tua maupun guru dapat mempengaruhi kepribadian anak sehingga mengakibatkan terbentuknya kepribadian yang mungkin tidak diinginkan. Pola asuh otoriter memberikan kontrol yang ketat pada anak sehingga dapat menimbulkan serentetan akibat negatif terhadap anak. Anak yang mendapatkan pola asuh otoritarian merasa tidak memiliki alternatif kecuali mengikuti segala yang dikehendaki orang tua. Tanpa mereka sadari, mereka akan kehilangan momen yang menyenangkan dalam hubungan dengan orang tua (Nilam, 2009). Beruntung jika ia memiliki kesempatan menerima kehangatan figur orang dewasa lainnya, seperti paman, bibi, kakek, nenek, guru dan lain sebagainya.

Berdasarkan latar belakang yang telah dipaparkan diatas, maka rumusan masalah dan tujuan pada penelitian ini antara lain: untuk mengetahui pengertian dari kepemimpinan dan gaya kepemimpinan otoriter, untuk mengetahui kebutuhan- 
kebutuhan pada anak usia remaja, untuk mengetahui pengaruh pengaruh gaya kepemimmpinan otoriter terhadap anak usia remaja, untuk mengetahui sisi positif dan negatif dari kepemimpinan otoriter bagi anak usia remaja, dan untuk mengetahui pengaruh jangka pendek dan jangka panjang dari penerapan pola asuh otoriter bagi anak usia remaja.

\section{B. METODE}

Metode yang digunakan pada penelitian ini adalah metode library research atau biasa disebut dengan studi kepustakaan. Metode studi kepustakaan adalah serangkaian kegiatan yang berkenaan dengan metode pengumpulan data pustaka, membaca, dan mencatat serta mengolah penelitian (Abdul, 2018). Sehingga informasi yang diperoleh pada jurnal ini berasal dari buku-buku, ensiklopedia, karya ilmiah, tesis, disertasi, situs web, dan lain-lain. Bahan referensi pada penelitian ini diperoleh dari teknik pengumpulan data dengan menyajikan penelitian-penelitian terdahulu yang berkaitan.

\section{PEMbahasan}

Menurut Gusti Ayu Rukmini melalui penelitiannya pada tahun 2019 tentang "Dampak Pola Asuh Orang Tua yang Otoriter terhadap Psikologis Remaja di Kelurahan Solo Kecamatanatang Sawitto Kabupaten Pinrang" untuk Tugas Akhir Skripsi (S1) UIN Alauddin Makassar bahwa pola asuh otoriter yang diterapkan oleh orang tua akan berdampak pada psikologis remaja, yaitu anak berperilaku agresif dan tidak percaya diri, kurang memiliki motivasi, takut untuk berpendapat, serta memiliki sifat egoism. Hendaknya orang tua tidak terlalu menerapkan pola asuh otoriter dan bersikap lebih terbuka kepada remaja (tidak mengekang) karena tidak semua remaja dapat menerima pola asuh tersebut (Gusti, 2019). Menurut Nova Riris Mirantika melalui penelitiannya pada tahun 2016 tentang "Hubungan Pola Asuh Permisif dan Otoriter dengan Kenakalan Remaja" untuk Tugas Akhir Skripsi (S1) Universitas Negeri Semarang bahwa kenakalan remaja pada siswa SMK Muhammadiyah Lasem disebabkan oleh pola asuh permisif sedangkan pola asuh otoriter tidaklah mempengaruhi kenakalan remaja pada siswa SMK Muhammadiyah Lasem. Akan tetapi dengan penerapan pola asuh otoriter secara berlebihan kepada anak akan mengakibatkan anak memiliki pribadi yang pemberontak, mudah tersinggung, penakut, mudah stress, pemurung, dan lain-lain (Nova, 2016). Menurut Nur Irmayanti mahasiswi Universitas Psikologi Wijaya Putra Surabaya melalui jurnal penelitiannya pada tahun 2016 tentang "Pola Asuh Otoriter, Self Esteem dan Perilaku Bullying" bahwa pola asuh otoriter dan self esteem memiliki korelasi dengan perilaku bullying anak. Karena orang tua selalu menekankan anak agar selalu patuh pada standar yang telah mereka tentukan dan menghukum anak dengan keras jika anak tidak sesuai dengan standar tersebut (Nur, 2016).

Menurut Nur Arofah Tis'ina dan Suroso pada jurnal penelitiannya pada tahun 2015 tentang "Pola Asuh Otoriter, Konformitas, dan Perilaku School Bullying" bahwa pola asuh disiplin otoriter memberikan dampak pada anak, antara lain anak menjadi pendiam dan penurut, tetapi sering menyimpan sakit hati atas perlakuan orang tua tersebut sehingga mengakibatkan anak 
menjadi tidak bahagia, tidak aman, dan percaya diri kurang (Nur Arofa, 2015). Menurut Inta Nilya Bahar melalui penelitiannya pada tahun 2008 tentang "Hubungan Antara Gaya Kepemimpinan Atasan Otoriter dengan Burnout" untuk Tugas Akhir Skripsi (S1) UIN Syarif Hidayatullah Jakarta bahwa gaya kepemimpinan otoriter menyebabkan anggota kelompok atau organisasi menjadi penurut dan tidak berani mengambil keputusan sehingga akan bergantung pada pimpinan. Anggota akan bersifat terpaksa dan pura-pura karena hanya dilakukan bila diawasi dan jika tidak melakukan akan dikenakan sanksi. Maka, jika suatu organisasi atau kelomppok menerapkan gaya kepemimpinan ini akan menimbulkan stress yang berkepanjangan akan menjadi burnout (Inta, 2008). Menurut Muchamad Ishak dan Yahya Ripki Puad pada jurnal penelitiannya pada tahun 2017 tentang "Gaya Mengajar Otoriter dan Demokratis terhadap Hasil Belajar Renang Gaya Bebas" bahwa aya mengajar otoriter memberikan pengaruh yang signifikan terhadap hasil belajar siswa. Akan tetapi gaya mengajar demokratis lebih signifikan pengaruhnya dibandingkan dengan gaya mengajar otoriter. Gaya mengajar otoriter sangat cocok untuk diterapkan pada situasi yang memerlukan keseriusan dan kedisiplinan serta pada situasi dimana peserta didikna kurang memiliki percaya diri dan merasa perlu perlindungan dari pendidik (Muchamad, 2017).

\section{Pengertian Gaya Kepemimpinan Otoriter}

Setiap orang adalah seorang pemimpin, baik pemimpin bagi dirinya, pemimpin bagi masyarakat sekelilingnya, dan pemimpin bagi keluarganya.
Seorang pemimpin harus bisa segani dan dipatuhi oleh para bawahannya. Kepemimpinan menurut Kadarusman terbagi menjadi 3 kepeimpinan yaitu self leadership, team leadership, dan organizational leadership. Team leadership berarti memimpin orang lain, organizational leadership berarti memimpin organisasi, dan self leadership berarti memimpin diri sendiri. Definisi dari kepemimpinan itu sendiri memiliki banyak definisi. Dari banyak definisi tentang kepemiminan, ada yang menyebutkan kepemimpinan merupakan suatu kegiatan untuk mempengaruhi orang lain (Fridayana, 2013). Kepemimpinan merupakan upaya mengarahkan atau mempengaruhi orang lain untuk mencapai suatu tujuan tertentu.

Dalam memimpin agar lebih efektif para pemimpin bisa menggunakan gaya yang bisa mencapai tujuannya. Gaya kepemimpinan adalah norma perilaku yang ditampilkan seseorang pada saat ia mempengaruhi orang lain (Sepni, 2019). Menurut Ruvendi gaya kepemimpinan merupakan salah satu faktor terpenting yang dapat mempengaruhi kepuasan kerja. Salah satu gaya yang bisa diterapkan oleh pemimpin pada bawahannya adalah gaya kepemimpinan otoriter. Dalam gaya otoriter ini pemimpin sebagai penguasa, semua bawahan hanya anggota yang harus menjalankan perintah dari pemimpinnya. Pemimpin dengan gaya otoriter memiliki pemikiran yang mana hanya dirinya yang paing hebat dan yang paling utama dari para anggota atau bawahannya.

Gaya kepemimpinan otoriter adalah gaya pemimpin yang memusatkan segala keputusan dan kebijakan yang diambil dari dirinya secara penuh (Patricia). Pemimpin 
yang otoriter dalam pengambilan keputusan ia mengambil keputusan sendiri tandap harus bertanya atau melihat bagaimana para anggota bawahannya. Segala semua keputusan atau melakukan kegiatan pada gaya otoriter ini seepenuhnya dikontrol oleh pemimpin. Gaya kepemimpinan otoriter ini akan berdampak tidak adanya kebersamaan, kegiatan yang bisa saja tidak terarah.

\section{Kebutuhan Anak Usia Remaja}

Kata "remaja" berasal dari bahasa Latin adolescene berarti to grow atau to grow maturity. Menurut Papalia dan Olds, masa remaja adalah masa transisi perkembangan antara masa kanak-kanak dan dewasa yang pada umumnya dimulai pada usia 12 atau 13 tahun dan berakhir pada usia akhir belasan atau awal dua puluh tahun (Khamim, 2017). Menurut Wirawan dalam mendefinisikan remaja seharusnya disesuikan dengan budaya setempat, sehingga untuk di Indonesia digunakan batasan usia remaja 1124 tahun dan belum menikah dengan pertimbangan- pertimbangan sebagai seperti, usia 11 tahun adalah usia di mana pada umumnya tanda-tanda sekunder mulai nampak, Pada masyarakat Indonesia, usia 11 tahun sudah dianggap akil baligh, baik menurut adatmaupun agama, sehingga masyarakat tidak lagi memperlakukan mereka sebagai anak-anak, pada usia tersebut mulai ada tanda-tanda penyempurnaan perkembangan jiwa seperti tercapainya identitas ego (menurut Ericson), tercapainya fase genital dari perkembangan psikoseksual (menurut Freud), dan tercapainya puncak perkembangan kognitif (menurut Piaget), maupun moral (menurut Kohlberg), batas usia 24 tahun adalah merupakan batas maksimal, yaitu untuk memberi peluang bagi mereka yang sampai batas usia tersebut masih menggantungkan diri pada orang tua, belum mempunyai hak-hak penuh sebagai orang tua, dan dalam definisi tersebut, status perkawinan sangat menentukan apakah individu masih digolngkan sebagai remaja ataukah tidak (Khamim, 2017).

Menurut Beumbrind (Papalia, 2004) pola asuh merupakan cara orang tua membesarkan anak dengan memenuhi kebutuhan anak, memberi perlindungan, mendidik anak, serta mempengaruhi tingkah laku anak dalam kehidupan sehari-hari. Hubungan remaja dengan orang tua yang buruk dapat mempengaruhi hubungan remaja dengan lingkungan di luar rumah. Sedangkan faktor-faktor yang mempengaruhi perkembangan dalam proses sosialisasi individu menurut Ali dan Anshori adalah terjadi di tiga lingkungan utama, yaitu lingkungan keluarga, lingkungan sekolah dan lingkungan masyarakat (Rahmatika, 2014). Pada remaja tahap awal, mereka lebih memiliki keinginan kuat untuk untuk tetap bergantung dengan orang tua. Remaja pada tahap pertengahan mengalami konflik terhadap kemandirian dan kontrol, sehingga pada tahap ini mereka lebih merasa terdorong untuk emansipasi dan pelepasan diri. Sebagai seorang guru atau orang tua harus dapat memahami bahwa anak usia remaja bertujuan agar mendapatkan kemandirian, memiliki perasaan yang sensitif dan sensitif terhadap segala perilaku yang mempengaruhinya, teman-teman merupakan hal yang sangat penting, remaja mempunyai kebutuhan yang kuat untuk memiliki, dan remaja memandang segala sesuatu sebagai baik dan buruk (Ade, 2014). 
3. Pengaruh Gaya Kepemimpinan Otoriter terhadap Anak Usia Remaja

Ada beberapa gaya kepemimpinan

yang dapat kita ketahui, salah satunya adalah kepemimpinan otoriter. Gaya kepemimpinan seseorang sangat mempengaruhi psikis seseorang, baik si pemimpin maupun yang dipimpin. Gaya kepemimpinan otoriter juga memiliki dampak positif dan negatif. Dampak negative dari gaya kepemimpinan otoriter adalah, anak akan berlaku pasif, memiliki kepribadian yang kaku, cenderung menarik diri, menghambat inisiatif anak. Orang tua dan guru yang mendidik anaknya dengan gaya otoriter ini cenderung lebih mendikte anak dan kurang memiliki hubungan yang erat terhadap anak atau peserta didik tersebut. Dampak lainnya anak akan merasa kurangnya kendapat kepercayaan dari orang tua sehingga anak tersebut sulit unutk mengembangkan dirinya karna harus selalu menunggu perintah dan tidak memiliki kepribadian yang kuat untuk menetapkan sesuatu pilihan. Anak dengan gaya kepemimpinan otoriter juga cenderung selalu berkerja dengan bergantung pada perintah orang lain. Sangat jarang dampak positif yang dihasilkan dari gaya kepemimpinan otoriter ini, kecuali orang tua dalam memrintah dan menghukum anak dapat membrikan alasan mengapa anak tersebut mendapatkan hukuman seeprti itu. Bisa dikatakan dalam gaya kepemimpinan otoriter apabila orang tua memebrikan perintah yang baik, seperti contohnya dalam hal bargaul pada masa sekrang, dan anak tersebut mengikuti perintah orang tua dan gurunya, ada kemungkinana besar anak tersebut dapat terhindar dari kenakalan remaja karna rasa takut merek kepada orang tua atau guru jauh lebih besar. Sebagai orang tua dan guru tentu kita tau bahwa kita sangat berperan penting dalam menentukan tingkat emosional anak kita atu anak didik kita. Oleh karena itu perlu adanya komuikasi yang erat antara anak dan orang tua, atau peserta didik dan guru, guna membangun suatu relasi yang baik agar dapat tercapainya tumuan hidup yang sesuai dengan norma dan aturan yang ada.

Pengaruh yang ditimbulkan dari gaya kepemimpinan otoriter ini bagi psikis dan masa depan anak sangatlah besar. Orang tua cenderung tidak memberikan kesempatan pada anak untuk mengutarakan perasaaannya. Maka dari itu timbulah dan terbentuknya sifat agresiv pada anak. Biasanya orang tua yang melakukan pola asuh otoriter ini juga sering melakukan kesalahan dengan menghukum atau memukul anak tanpa memberikan alasan yang jelas. Tentu sikap orang tua atau guru yang seperti ini sangat berdampak pada tingkat emosional si anak. Anak cenderung aan mempunyai emosi yang meledak ledak karna meniru atau mencontoh dari apa yang orang tua mereka lakukan kepada dirinya. Perkembangan sosial dan emosional anak juga dapat terganggu, dan dapat mempengaruhi bagaimana cara anak tersebut dalam memperlakukan seseorang.

Oleh karena itu pentingnya bagi para orang tua dan guru untuk mengetahui pola asuh untuk anak mereka masing masing. Karna cara orang tua mengajarkans esuatu kepada anak akan sangat berpengaruh paa kehidupannya dimasa sekarang dan masa depan. 


\section{KESIMPULAN}

Kepemimpinan merupakan suatu kegiatan untuk mempengaruhi orang lain. Kepemimpinan merupakan upaya mengarahkan atau mempengaruhi orang lain untuk mencapai suatu tujuan tertentu. Gaya kepemimpinan adalah norma perilaku yang ditampilkan seseorang pada saat ia mempengaruhi orang lain. Menurut Ruvendi gaya kepemimpinan merupakan salah satu faktor terpenting yang dapat mempengaruhi kepuasan kerja. Salah satu gaya yang bisa diterapkan oleh pemimpin pada bawahannya adalah gaya kepemimpinan otoriter. Pemimpin yang otoriter dalam pengambilan keputusan ia mengambil keputusan sendiri tandap harus bertanya atau melihat bagaimana para anggota bawahannya. Menurut Beumbrind (Papalia, 2004) pola asuh merupakan cara orang tua membesarkan anak dengan memenuhi kebutuhan anak,memberi perlindungan, mendidik anak, serta mempengaruhi tingkah laku anak dalam kehidupan sehari-hari.

Faktor-faktor yang mempengaruhi perkembangan dalam proses sosialisasi individu menurut Ali dan Anshori adalah terjadi di tiga lingkungan utama, yaitu lingkungan keluarga, lingkungan sekolah dan lingkungan masyarakat. Orang tua dan guru yang mendidik anaknya dengan gaya otoriter ini cenderung lebih mendikte anak dan kurang memiliki hubungan yang erat terhadap anak atau peserta didik tersebut. Sangat jarang dampak positif yang dihasilkan dari gaya kepemimpinan otoriter ini, kecuali orang tua dalam memerintah dan menghukum anak dapat memberikan alasan mengapa anak tersebut mendapatkan hukuman seeprti itu. Bisa dikatakan dalam gaya kepemimpinan otoriter apabila orang tua memberikan perintah yang baik, seperti contohnya dalam hal bargaul pada masa sekrang, dan anak tersebut mengikuti perintah orang tua dan gurunya, ada kemungkinana besar anak tersebut dapat terhindar dari kenakalan remaja karna rasa takut merek kepada orang tua atau guru jauh lebih besar.

\section{E. DAFTAR PUSTAKA}

\section{Buku.}

Kattani, Abdul Hayyie Al \& Wido Supraha. (2018). Menumbuhkan Karakter Anak (Perspektif Ibn Abd Al-Barr AlAndalusi. Yogyakarta: Penerbit Deepublish.

Paramita, P. D. (2011). Gaya Kepemimpinan (Style of Leadership) yang Efektif dalam Suatu Organisasi. Dinamika Sains, 9 (21).

Yudiaatmaja, F. (2013). Kepemimpinan:

Konsep, Teori Dan Karakternya. Media Komunikasi FIS, 12(2).

\section{Jurnal.}

Bahar, Inta Nilya. (2008). "Hubungan Antara Gaya Kepemimpinan Atasan Otoriter dengan Burnout". Skripsi Fakultas Psikologi Universitas Islam Negeri Syarif Hidayatullah, Jakarta 2008.

Febriana, Rahmatika. (2014). "Perbedaan Capaian Perkembangan Sosial Antara Remaja Yang Tinggal Di Panti Asuhan dan Remaja Yang Tinggal Bersama Orang Tua di Mts Taqwa Ilah Semarang”. Jurnal Ilmiah Psikologi, 6(1)

Hidayat. (2019). Kepe"mimpinan dan supervise pendidikan". Banten: YPSIM 
Hidayati, Nur Istiqomah. (2014). "Pola Asuh Otoriter Orang Tua, Kecerdasan Emosi, dan Kemandirian Anak SD." Persona: Jurnal Psikologi Indonesia 3(1)

Irmayanti, Nur. (2016). "Pola Asuh Otoriter Self Esteem dan Perilaku Bullying", Jurnal Penelitian Psikologi 7(01). 2035.

Ishak, Muchamad \& Yahya Ripki Puad. (2017). "Gaya Mengajar Otoriter dan Demokratis terhadap Hasil Belajar Renang Gaya Bebas". Jurnal Pendiidikan Jasmani dan Olahraga 2(1). 94- 103.

Kurniasih, Wulan, dan Wiwien Dinar Pratisti. (2013). "Regulasi emosi remaja yang diasuh secara otoriter oleh orangtuanya."

Mirantika, Nova Riris. (2016). "Hubungan Pola Asuh Pemisif dan Otoriter dengan Kenakalan Remaja”. Skripsi Fakultas Ilmu Pendidikan Universitas Negeri Semarang.

Munawir, Muhammad. (2016). "Dampak perbedaan pola asuh terhadap perilaku agresif remaja di SMA 5 Peraya." Psychology \& Humanity 2 19-20.

Putu, Ni Ayu. (2016). "Hubungan Antara Kecenderungan Pola Asuh Otoriter (Authoritarian Parenting Style) dengan Gejala Perilaku Agresif Pada Remaja". Jurnal Psikologi Udayana, 3(1)

Rukmini, Gusti Ayu. (2019). "Dampak Pola Asuh Orang Tua yang Otoriter terhadap Psikologis Remaja di Kelurahan Salo Kecamatan Watang Samito Kabupaten Pinrang". Skripsi Fakultas Dakwah dan Komunikasi
Universitas Islam Negeri Alauddin.

Suteja, Jaja, dan Yusriah Yusriah. (2017). "Dampak pola asuh orang tua terhadap perkembangan sosialemosional anak." AWLADY: Jurnal Pendidikan Anak 3(1)

Tis'ina, Nur Arofa \& Suroso. (2015). "Pola Asuh Otoriter, Konformitas, dan Perilaku School Bullying”. Jurnal Psikologi Indonesia 4(2). 153-161.

Widyarini, Nilam. (2009). "Seri psikologi popular: relasi orang tua dan anak". Surabaya: Elex Media Komputindo

Wulandari, Ade. (2014). "Karakteristik Pertumbuhan Perkembangan Remaja dan Implikasinya Terhadap Masalah Kesehatan dan Keperawatan". Jurnal Keperawatan Anak, 2(1)

Yanti, S. (2019). "Gaya Kepemimpinan Guru Sd Sekolah Dasar Di Dalam Kelas. Jurnal Pendidikan Dasar Perkhasa", Jurnal Penelitian Pendidikan Dasar, 5(1), 66-72.

Zarkasih, Khamim. (2017). "Memahami ciri dan tugas perkembangan masa remaja". Jurnal Aplikasi Ilmu-Ilmu Agama, 17(1) 